\title{
RADIOCARBON DATING OF AHDNAME, MANTEL AND ARMORIAL FROM THE FOJNICA FRANCISCAN MONASTERY, BOSNIA AND HERZEGOVINA
}

\author{
Nada Horvatinčić ${ }^{1}$, Andreja Sironić ${ }^{1}$, Jadranka Barešić ${ }^{1}$, Igor Kozjak ${ }^{2}$ \\ ${ }^{1}$ Laboratory for Low-level Radioactivities, Department of \\ Experimental Physics, Ruđer Bošković Institute, Bijenička 54, \\ Zagreb, Croatia \\ ${ }^{2}$ Central Laboratory for Conservation and Restoration, Croatian \\ State Archives, Marko Marulić Square 21, Zagreb, Croatia
}

\begin{abstract}
In this work, we present the results of radiocarbon (14C) dating of three historically important objects related to the period of the reign of the Ottoman Empire in Europe. The following objects from the museum collection of the Franciscan Monastery in Fojnica, Bosnia and Herzegovina were 14C dated: (1) paper from the Ahdname (Fojnička ahdnama); (2) textile of the mantel of Fra Anđeo Zvizdović; and (3) paper from the Fojnica Armorial (Fojnički grbovnik). It was assumed that the Ahdname was issued in AD 1463 by the Ottoman Sultan Mehmed II to the Catholic monks and that the Mantel had belonged to Fra Anđeo Zvizdović, who received the Ahdname. The Fojnica Armorial is an important source of the classical heraldry of the Balkans Peninsula, with various estimates of the age. The 14C calibrated ages of the Ahdname are as follows: lower part, cal AD 1430-1465, upper part, cal AD 1665-1808, proving that only the lower part of the Ahdname was original. The 14C calibrated age of the textile from the outer layer of the Mantel is cal AD 1492-1641, somewhat younger than expected, and inner lining even younger, cal AD 1652-1805. Good coincidence between the calibrated age span of the renewed part of the Ahdname and the lining material of the Mantel can suggest that both objects had been renewed around the same time. Two samples of the Fojnica Armorial were dated: thick paper, cal AD 1631-1667 and thin paper, cal AD 1809-1926, showing that the Armorial had been compiled during different periods.
\end{abstract}

KEYWORDS: radiocarbon dating, Fojnica Ahdname, Fojnica Armorial, Franciscan Monastery in Fojnica

\section{INTRODUCTION}

Dating of objects of cultural heritage and art is essential for their evaluation, for differentiation between the original works and later imitations, and for recognition of repaired and/or restored works. Accurately dated objects of cultural heritage also can be particularly important to the history of the region or nation. In this work, we present the radiocarbon age data of historically important objects from the museum collection of the Franciscan Monastery of the Holy Spirit in Fojnica, Bosnia and Herzegovina.

Fojnica $\left(43^{\circ} 58^{\prime} \mathrm{N}, 17^{\circ} 54^{\prime} \mathrm{E}\right)$ is a town and municipality in central Bosnia and Herzegovina, located west of the capital Sarajevo. The Monastery was founded in AD 1668 and houses an 
important part of the nation's cultural heritage. It includes a library of cca. 12,500 volumes, including 13 incunabulas and 156 works written in Bosnian Cyrillic. Most of the works are philosophical and theological, printed from the $16^{\text {th }}$ to the $19^{\text {th }}$ centuries. The library archive preserves more than 3,000 documents from the Ottoman Empire, with 13 of them dating back to AD 1481.

Over the centuries, the activity of the Franciscan monks was in numerous cases essential in keeping religious and national identity by collecting and preserving historically important documents. The collection in the Monastery museum holds the $15^{\text {th }}$ century Ahdname (Fojnička ahdnama) (Figure 1A). An Ahdname is a type of the Ottoman charter commonly referred to as a treaty. It was an important part of the Ottoman diplomacy in that it set forth a contractual agreement between two states, usually between the Ottoman Empire and European nations (Theunissen 1998; Oršolić 2000; Goffman 2002). It was influential in the way it helped to structure society and maintained the agreements made between nation - states. The well-known examples of Ottoman Ahdnames were the Venetian Ahdnames (list of 24 ahdnames in period from $\mathrm{AD} 1403$ to $\mathrm{AD} 1641$ ), used to maintain political and commercial links between the Venice and the Ottoman Empire. Also, the Ottoman Empire imposed Ahdnames on the Republic of Ragusa (present Dubrovnik, Croatia) from AD 1458 to AD 1649 (in total 14 documents, of which most were destroyed) (Miović and Selmani, 2007). The Republic of Raguza was required to give up their sovereignty to the Ottoman Empire because they had become a tributory state of the Empire. The Fojnička ahdnama is assumed to had been issued by Sultan Mehmed II the Conquirer in AD 1463 to the Catholic monks of recently-conquered Bosnia, granting them full religious freedom and protection. According to the historical event, the Ahdname was taken over by Fra Anđeo Zvizdović in AD 1463 (May 28 ${ }^{\text {th }}$ ) from the Ottoman Sultan Mehmed II the Conqueror in the military camp Milodraže near Fojnica, Bosnia (present Bosnia and Herzegovina) (Šabanović 1949, Džaja 2012). The collection in the Monastery museum holds the Mantel that is assumed to have belonged to Fra Anđeo Zvizdović (lived AD 1420 - AD 1498) (Figure 2A). In 2013 the $550^{\text {th }}$ anniversary of the event was celebrated in the Milodraže land.

The museum also houses the Book of Coats of Arms so-called the Fojnica Armorial (Fojnički grbovnik) (Figure 3A and 3B). Armorials are individual families' collections of coats of arms, dating back to the early Middle Ages. Their purpose was to confirm those families' lineal decent from the noble ancestors. Armorials are highly relevant as primary heraldic sources, both for the coats of arms of the individual families and the entire kingdoms. The oldest armorial in the 
Balkan region is the Korenić-Neorić Armorial which was made in the late $16^{\text {th }}$ century (AD 1595) and is being kept in the National and University Library in Zagreb, Croatia. The later armorials, such as the Fojnica Armorial, the only known one in Bosnia and Herzegovina, were designed on the basis of that armorial (Fojnički grbovnik 2012). The manuscript is named after the Franciscan monastery in Fojnica where it was kept. It contains a total of 139 coats of arms of some Balkan countries and then-prominent Bosnian families. The size of the Armorial is $30.4 \mathrm{~cm} \times 20.5 \mathrm{~cm}$. There are various estimates of its age, from $16^{\text {th }}$ to $18^{\text {th }}$ century, most likely the book dates to the Great Turkish War (AD 1683 - 1699) or to a period leading up to the War, i.e. in the context of the rebellions against the Ottoman rule during the War (Fojnički grbovnik 2012).

All three objects from the collection of the Fojnica monastery have great importance for interpretation of history in the Bosnia region, particularly in the very turbulent period when the Ottoman Empire occupied most of the SE Europe and intended to expand further to Europe. Furthermore, the Franciscan Monastery in Fojnica suffered several fires in that period (Džaja 2012). Consequently, there are doubts whether these documents are authentic or not (Boškov, 1979; Džaja 2012). Using radiocarbon dating of different materials from these objects, we tried to evaluate the authenticity of the Fojnica Ahdname, the Mantel of Fra Anđeo Zvizdović and the Fojnica Armorial.

\section{MATERIALS AND METHODS}

All materials were carefully sampled, pre-treated, processed to graphite and measured by AMS. Particularly sensitive was sampling of the Ahdname, which consisted of a paper measuring 46.6 $\mathrm{cm} \times 17.3 \mathrm{~cm}$, mostly covered with Arabic letters written in Turkish (Figure 1A). Very careful inspection of the Ahdname by the paper experts from the Croatian State Archives showed that the document consisted of two parts of paper glued together: the upper part with red Arabic letters, and the lower part with black Arabic letters. It had been restored with Japanese tissue and laminated with plastic foil. For radiocarbon dating, the paper was sampled by carefully cutting $\sim 2 \mathrm{~cm}^{2}$ of paper ( $\sim 90 \mathrm{mg}$ ) from both the upper and lower portions. The paper samples were soaked in decahydronaphthalene (decalin) (Dadić and Ribkin 1970) to separate the plastic foil after which the Japanese paper was removed. The paper adhesive was removed by dissolution in hot water. Both samples were then treated by $\mathrm{ABA}$ method at $80^{\circ} \mathrm{C}$ and freeze dried. 
The Mantel (Figure 2A) consisted of two types of textile: a dark blue-colored with gold-colored stars outer layer and a red-colored inner lining. The outer layer was manufactured from wool, and the lining from linen. The samples were examined by a binocular microscope and appeared to be relatively clean, but were also additionally microscopically examined after each pretreatment step. The samples were soaked in acetone in ultrasonic bath, in order to remove any possible grease like molecules, and rinsed thoroughly with ultra-pure water (adapted after Bruhn et al. 2001), followed by ultrasonic bleaching by $1 \%$ sodium hypochlorite solution and then ABA method at room temperature (Van Strydonck et al. 2004; Brock et al. 2010). The samples were freeze dried.

The Fojnica Armorial (Figures 3(A and B) was composed of two types of paper, thick and thin paper, both of which were dated ( $~ 80 \mathrm{mg}$ and $\sim 50 \mathrm{mg}$ of paper, respectively). Paper samples were treated by $\mathrm{ABA}$ method at $80^{\circ} \mathrm{C}$ and freeze dried.

Pretreated paper and textile samples were further processed to graphite for the AMS measurement. Graphite targets were prepared by the following chemical procedures: 1) $\mathrm{CO}_{2}$ production by oxidation in presence of $\mathrm{CuO}$ and $\mathrm{Ag}$ at $\left.850^{\circ} \mathrm{C}, 2\right)$ reduction of $\mathrm{CO}_{2}$ by $\mathrm{Zn}$ at $450^{\circ} \mathrm{C}$ to graphite and iron powder at $550^{\circ} \mathrm{C}$ as a catalyst (Krajcar Bronić et al. 2010; Sironić et al. 2013). The ${ }^{14} \mathrm{C}$ AMS measurement of graphite targets was performed in Scottish Universities Environmental Research Centre (SUERC, East Kilbride, Scotland) Radiocarbon Laboratory (see Table 1 and 2, GU code) and the Centre for Applied Isotope Studies, University of Georgia (Athens, Georgia, USA) (see Table 1, 2 and 3, UGAMS code). Aliquots of $\mathrm{CO}_{2}$ gas prepared from the samples were analyzed for $\delta^{13} \mathrm{C}$ on IRMS in the respective Laboratories.

The ${ }^{14} \mathrm{C}$ results were calibrated using the software OxCal v 4.2.4 (Bronk Ramsey 2009, 2016) and IntCal13 calibration curves (Reimer et al. 2013).

\section{RESULTS AND DISCUSSION}

The results are presented separately for the Ahdname document (Fojnička ahdnama), the Mantel of Fra Anđeo Zvizdović, and the Fojnica Armorial (Fojnički grbovnik.). All results are presented as conventional ${ }^{14} \mathrm{C}$ ages and calibrated age spans of the highest posterior density range within $2 \sigma$, as well as median cal $A D$ values. If a sample was measured twice, the weighted mean value of the two measurements obtained by using chi-squared statistics to justify combining dates (R-combine function in OxCal (Bronk Ramsey 2009, 2016)) was used for 
calibrated age span. For comparison, expected or assumed ages are also given. In Figure 4, we show the summary of all ${ }^{14} \mathrm{C}$ results presented as the calibrated ${ }^{14} \mathrm{C}$ data distribution for individual and combined data within $2 \sigma$ confidence.

\section{The Fojnica Ahdname (Fojnička ahdnama)}

As described above, the Ahdname (Figure 1A) consisted of two parts of paper glued together, both of which were dated. Both parts of the Ahdname were measured twice with two graphite sample preparations and the ${ }^{14} \mathrm{C}$ results of all measurements are presented in Table 1 and Figure 4. In Figure 1 the calibrated curves for the weighted mean values of ${ }^{14} \mathrm{C}$ ages of the upper (Figure 1B) and the lower part (Figure 1C) of the Ahdname paper are presented. The results of lower part of the Ahdname (Z-5126) show the narrow calibrated age span of two ${ }^{14} \mathrm{C}$ results and combined data, with slight difference between two measurements (Figure 4), but still in good statistical agreement $(\mathrm{t}=2.3$ ) (Figure $1 \mathrm{C}$ ). The calibrated age span, cal AD $1430-1465$ (probability 95.4\%), corresponded with the expected/historical age of the Ahdname (AD 1463). The results of the upper part of the Ahdname (Z-5124) showed significantly wider calibrated age span, cal AD 1665 - 1808 (probability 73.8\%), cal AD 1928 - ... (21.6\%). There was good agreement with both individual measurements (chi-square test, $\mathrm{t}=2.0$ ) (Figure 1B), but not with the lower part (Figure 4), i.e. it was younger than the original Ahdname document. The ${ }^{14} \mathrm{C}$ age of the lower part of the Ahdname proved that this part was original, while the age of the upper part was approximately 300 years too young. It seems very likely that the Ahdname had been damaged or partly destroyed sometime in the past and restored afterwards. According to the opinion of monks in Franciscan Monastery in Fojnica the Ahdname was renewed in 17 18 century. There was no written evidence about that, only oral tradition. Consequently, the 20 century result (cal AD $1928-\ldots, 21.6 \%$ ) was rejected in the result interpretation. 
Table 1 Results of ${ }^{14} \mathrm{C}$ dating of the Ahdname paper samples, for individual measurements and weighted mean values. The highest posterior density range of calibrated age span within $2 \sigma$ is given in bracket. GU code - Glasgow University and UGAMS code - University of Georgia.

\begin{tabular}{|c|c|c|c|c|c|c|c|}
\hline $\begin{array}{l}\text { Lab } \\
\text { code }\end{array}$ & Sample name & $\begin{array}{c}\text { No. } \\
\text { measurement }\end{array}$ & $\begin{array}{l}\text { Conventional } \\
{ }^{14} \mathrm{C} \text { age (BP) }\end{array}$ & $\begin{array}{l}\delta^{13} \mathrm{C} \\
(\% \circ)\end{array}$ & $\begin{array}{l}\text { Calibrated age } \\
\text { (cal AD) }\end{array}$ & $\begin{array}{c}\text { Median } \\
\text { (cal AD) }\end{array}$ & $\begin{array}{l}\text { Expected } \\
\text { age (AD) }\end{array}$ \\
\hline \multirow[t]{3}{*}{ Z-5124 } & \multirow{3}{*}{$\begin{array}{l}\text { The Ahdname } \\
\text { paper, upper part }\end{array}$} & 1. (GU30373) & $213 \pm 28$ & -25.6 & \multirow[b]{3}{*}{$\begin{array}{c}\mathbf{1 6 6 5}-\mathbf{1 8 0 8} \\
(73.8 \%)\end{array}$} & \multirow[b]{3}{*}{1769} & \multirow[b]{3}{*}{1463} \\
\hline & & 2. (UGAMS24490) & $163 \pm 21$ & -25.6 & & & \\
\hline & & mean & $181 \pm 17$ & & & & \\
\hline \multirow[t]{3}{*}{ Z-5126 } & \multirow{3}{*}{$\begin{array}{l}\text { The Ahdname } \\
\text { paper, lower part }\end{array}$} & 1. (GU30375) & $408 \pm 26$ & -23.6 & \multirow[b]{3}{*}{$\begin{array}{c}\mathbf{1 4 3 0}-\mathbf{1 4 6 5} \\
(95.4 \%)\end{array}$} & \multirow[b]{3}{*}{1445} & \multirow[b]{3}{*}{1463} \\
\hline & & 2. (UGAMS24494) & $459 \pm 21$ & -24.7 & & & \\
\hline & & mean & $439 \pm 17$ & & & & \\
\hline
\end{tabular}

\section{The Mantel of Fra Anđeo Zvizdović}

It was assumed that the dated mantel belonged to Fra Anđeo Zvizdović (Figure 2A), who received the Ahdname in AD 1463 from the Sultan Mehmed II, so it was expected that the age of the Mantel would correspond to that of the Ahdname. Two textile samples from outer layer and inner lining of the Mantel were dated separately and the results are presented in Table 2 and Figure 4. In Figure 2 the calibrated curves for the ${ }^{14} \mathrm{C}$ age for both textile samples are presented. The results of the Mantel outer layer (Z-5125) showed relatively wide calibrated age span for two ${ }^{14} \mathrm{C}$ measurements and their combined result and a good coincidence between two individual measurements (chi-square test, $\mathrm{t}=2.0$ ) (Figure 4). The age span of combined data, cal AD $1492-1641$ (95.4\%) is younger than expected (AD 1463). However, selected individual measurements of the Ahdname - the lower part (Z-5126/1, cal AD 1436 - 1516, 85.8\%) and the Mantel outer layer (Z-5125/1, cal AD 1452 - 1530, 46.7\%) are partly overlapping (Figure 4) (chi-square test, $t=7.2$ ). In this case, the calibrated age span of the Mantel of Fra Anđeo Zvizdović would correspond to a historical event when the Ahdname was received by Fra Anđeo Zvizdović in AD 1463 from the Ottoman Sultan Mehmed II. The radiocarbon result of the Mantel, lining material (Z-6039), showed wide calibrated age span, cal AD 1652 - 1805 (74.7\%), cal AD 1935 (20.7\%), younger than outer layer indicating that the lining had been restored. A very good agreement of the calibrated age of the lining with the upper part of the Ahdname (Z-5124) was observed (chi-square test $\mathrm{t}=0.5)$ (Figure 4$)$ which could suggested that both, the Ahdname upper part, and the Mantel lining material, had been renewed in the same 
time. For the final interpretation of the result the recent age (cal AD $1935-\ldots, 20.7 \%$ ) was rejected for the same reason as was described for the Ahdname, as it is younger than historical records for the mantel.

Table 2 Results of ${ }^{14} \mathrm{C}$ dating of the Mantel, two types of textile samples, for individual measurements and weighted mean value. The highest posterior density range of calibrated age span within $2 \sigma$ is given in bracket. GU code - Glasgow University and UGAMS code University of Georgia

\begin{tabular}{|c|c|c|c|c|c|c|c|}
\hline $\begin{array}{l}\text { Lab } \\
\text { code }\end{array}$ & Sample name & $\begin{array}{c}\text { No. } \\
\text { measurement }\end{array}$ & $\begin{array}{l}\text { Conventional } \\
{ }^{14} \mathrm{C} \text { age (BP) }\end{array}$ & $\begin{array}{l}\delta^{13} \mathrm{C} \\
(\% \circ)\end{array}$ & $\begin{array}{l}\text { Calibrated age } \\
\text { (cal AD) }\end{array}$ & $\begin{array}{l}\text { Median } \\
\text { (cal AD) }\end{array}$ & $\begin{array}{l}\text { Expected } \\
\text { age (AD) }\end{array}$ \\
\hline \multirow[t]{3}{*}{ Z-5125 } & \multirow{3}{*}{$\begin{array}{l}\text { The Mantel - } \\
\text { outer layer blue- } \\
\text { colored textile }\end{array}$} & 1. (GU30374) & $357 \pm 28$ & -23.6 & & & \\
\hline & & 2. (UGAMS24501) & $307 \pm 21$ & -23.4 & & & \\
\hline & & mean & $325 \pm 17$ & & $\begin{array}{c}\mathbf{1 4 9 2}-\mathbf{1 6 4 1} \\
(95.4 \%)\end{array}$ & 1567 & 1463 \\
\hline Z-6039 & $\begin{array}{l}\text { Lining material of } \\
\text { the Mantel - red- } \\
\text { colored textile }\end{array}$ & 1. (UGAMS24500) & $200 \pm 21$ & -24.1 & $\begin{array}{c}1652-1805 \\
(74.7 \%)\end{array}$ & 1779 & 1463 \\
\hline
\end{tabular}

\section{The Fojnica Armorial (Fojnički Grbovnik)}

Two samples of paper (thick and thin) of the Fojnica Armorial (Figure 3A and 3B) were dated and the ${ }^{14} \mathrm{C}$ results are presented in Table 3 and Figure 4. In Figure $3 \mathrm{C}$ the calibrated curve for the thick paper showed the calibrated age spans, cal AD 1523 - 1559 (23.8\%) and cal AD 1631 - $1667(67.1 \%)$. The first interval could be rejected since the Fojnica Armorial was made after 1595, see Introduction (Fojnički grbovnik 2012). Thin paper showed calibrated age spans, cal AD 1689 - 1730 (26.4\%) and cal AD 1809 - 1926 (69.0\%) (Figure 3D). The calibrated ${ }^{14} \mathrm{C}$ ages showed that the Fojnica Armorial consisted of the papers of different ages suggesting that the Armorial was compiled over different times. The watermarks which were found in many of the pages in the Armorial corresponded to the paper from the period of the $16^{\text {th }}$ to the mid of $17^{\text {th }}$ century. This observation was made in the Croatian Academy of Science, Zagreb, in 2011 (Fojnički grbovnik 2012). Our results of calibrated ages of the thick paper (Z-5700) are in good agreement with this assessment. 
Table 3 Results of ${ }^{14} \mathrm{C}$ dating of the Fojnica Armorial. The density range of the calibrated age spans within $2 \sigma$ is given in bracket.

\begin{tabular}{|c|c|c|c|c|c|c|}
\hline $\begin{array}{l}\text { Lab } \\
\text { code }\end{array}$ & Sample name & $\begin{array}{l}\text { Conventional } \\
{ }^{14} \mathrm{C} \text { age (BP) }\end{array}$ & $\begin{array}{l}\delta^{13} \mathrm{C} \\
(\%)\end{array}$ & $\begin{array}{c}\text { Calibrated age } \\
\text { (cal AD) }\end{array}$ & $\begin{array}{l}\text { Median } \\
\text { cal AD }\end{array}$ & $\begin{array}{c}\text { Expected age } \\
\text { (AD) }\end{array}$ \\
\hline $\begin{array}{l}\text { Z-5700 } \\
\text { (UGAMS } \\
\text { 20363) }\end{array}$ & $\begin{array}{l}\text { The Fojnica } \\
\text { Armorial - the } \\
\text { thick paper }\end{array}$ & $267 \pm 21$ & -25.6 & $\begin{array}{c}1523-1559 \\
(23.8 \%) \\
1631-1667 \\
(67.1 \%)\end{array}$ & 1645 & $\begin{array}{l}\text { from } 16^{\text {th }} \text { to } \\
18^{\text {th }} \text { century }\end{array}$ \\
\hline $\begin{array}{l}\text { Z-5701 } \\
\text { (UGAMS } \\
\text { 20364) }\end{array}$ & $\begin{array}{l}\text { The Fojnica } \\
\text { Armorial - the } \\
\text { thin paper }\end{array}$ & $103 \pm 21$ & -24.9 & $\begin{array}{c}1689-1730 \\
(26.4 \%) \\
1809-1926 \\
(69.0 \%)\end{array}$ & 1840 & $\begin{array}{l}\text { from } 16^{\text {th }} \text { to } \\
18^{\text {th }} \text { century }\end{array}$ \\
\hline
\end{tabular}

\section{CONCLUSION}

${ }^{14} \mathrm{C}$ dating of the three historically important documents/objects related to the period of the reign of the Ottoman Empire in SE Europe, from $15^{\text {th }}$ to $20^{\text {th }}$ century, which particularly influenced the region of the Bosnia, enabled to evaluate the originality of the objects. The ${ }^{14} \mathrm{C}$ results of the Ahdname, the Mantel of Fra Anđeo Zvizdović and the Fojnica Armorial, all of them from the museum collection of the Franciscan Monastery in Fojnica, Bosnia and Herzegovina, showed the following:

1. The Fojnica Ahdname (Fojnička ahdnama): the lower part of the Ahdname corresponds to the original document/historical age from AD 1463 (cal AD 1430 - 1465, 95.4\%); the upper part of the Ahdname is younger than the original (cal AD $1665-1808,73.8 \%$ ), indicating that the later part of the document had been repaired afterwards.

2. The Mantel which was assumed to have belonged to Fra Anđeo Zvizdović, who had received the Ahdname in AD 1463 from Sultan Mehmed II, in the military camp Milodraže near Fojnica, Bosnia, is younger than expected (cal AD 1492 - 1641, 95.4\%). However, partial overlapping of the individual measurements of the Ahdname and the Mantel, outer layer, could suggest that the Mantel belonged to Fra Anđeo Zvizdović. Additionally, the lining material of the Mantel was younger (cal AD 1652 - 1805, 74.7\%). Good agreement between the calibrated age span of the renovated part of the Ahdname and the linig material of the Mantel can suggest that both objects had been renewed in the same time.

3. The Fojnica Armorial (Fojnički Grbovnik) was composed of two types of paper of different ages: the thick paper, cal AD 1631 - 1667 (67.1\%), and the thin paper, cal AD $1689-1730$ 
(26.4\%), cal AD 1809 - 1926 (69.0\%). This indicates that the Armorial had been compiled in different times.

\section{ACKNOWLEDGEMENTS}

We specially thank Fra Nikica Vujica, the guardian of the Franciscan Monastery of the Holy Spirit in Fojnica, who initiated the dating of the presented objects from the museum collection of the Monastery. We also thank Ms. Tatjana Mušnjak from the Croatian State Archives for useful cooperation.

\section{REFERENCES}

Boškov V. 1979. Pitanje autentičnosti Fojničke ahd-name Mehmeda II iz 1463.godine. (The question of authenticity of Fojnička ahdnama of Mehmed II from 1463) Godišnjak Društva istoričara BiH 28-30:87-105.

Brock F, Higham T, Ditchfield P, Bronk Ramsey C. 2010. Current pretreatement methods for AMS radiocarbon dating at the Oxford Radiocarbon Accelerator Unit (ORAU). Radiocarbon 52(1):103-12.

Bronk Ramsey C. 2009. Bayesian analysis of radiocarbon dates. Radiocarbon 51(1):337-60.

Bronk Ramsey C. 2016. The OxCal program v 4.2. The Oxford Radiocarbon Accelerator Unit, University of Oxford. URL: https://c14.arch.ox.ac.uk/oxcal/OxCal.html

Bruhn F, Duhr A, Grootes P, Mintrop A, Nadeau MJ. 2001. Chemical removal of conservation substances by soxhlet'-type extraction. Radiocarbon 43(2A):229-37.

Dadić V, Ribkin T. 1970. Techniques of delaminating polyethylene laminates. International journal for the preservation of library and archival material 1 (3):144-8.

Džaja S. 2012. Fojnička ahdnama u zrcalu paleografije, pravne povijesti i politike (The Fojnička ahdnama in the mirror of paleography, legal history and politics), Poseban prilog Svjetla riječi (Special supplement of „Svijetlo riječi“): p. 1-16.

Fojnički grbovnik (The Fojnica Armorial) 2012. Franjevački samostan Fojnica (The Franciscan monastery in Fojnica). p 334.

Goffman D. 2002. The Ottoman Empire and Early Modern Europe. New York: Cambridge University Press. 265.

Krajcar Bronić I, Horvatinčić N, Sironić A, Obelić B, Barešić J, Felja I. 2010. A new graphite preparation line for $\mathrm{AMS}{ }^{14} \mathrm{C}$ dating in the Zagreb Radiocarbon Laboratory. Nuclear Instruments and Methods in Physics Research B 268 (7/8): 943-6.

Miović V and Selmani N. 2007. Turkish chancellery and Acta Turcarum from the period of the Dubrovnik Republic until the present. Anali Zavoda za povijesne znanosti Hrvatske akademije znanosti i umjetnosti u Dubrovniku 45: 235-84. 
Oršolić M. 2000. Ahdnama - standardno pravo ili neponovljivi privilegij (Ahdname - standard right or a unique privilege). Zbornik radova sa Znanstvenog skupa u povodu 500. obljetnice smrti Fra Andela Zvizdovića (Proceedings of the symposium to mark the 500th anniversary of the death of Fra Anđeo Zvizdović). p 363-92.

Reimer PJ, Bard E, Bayliss A, Beck JW, Blackwell PG, Bronk Ramsey C, Buck CE, Cheng H, Edwards RL, Friedrich M, Grootes PM, Guilderson TP, Haflidason H, Hajdas I, Hatté C, Heaton TJ, Hoffmann DL, Hogg AG, Hughen KA, Kaiser KF, Kromer B, Manning SW, Niu M, Reimer RW, Richards DA, Scott EM, Southon JR, Staff RA, Turney CSM, van der Plicht J. 2013. IntCal13 and Marine13 Radiocarbon Age Calibration Curves 0-50,000 Years cal BP, Radiocarbon 55(4):1869-87.

Sironić A, Krajcar Bronić I, Horvatinčić N, Barešić J, Obelić B, Felja I. 2013. Status report on the Zagreb Radiocarbon Laboratory - AMS and LSC results of VIRI intercomparison samples. Nuclear Instruments and Methods in Physics Research B 294:185-8.

Šabanović H. 1949. Turski dokumenti u Bosni iz druge polovice XV stoljeća (Turkish documents in Bosnia in the second half of the XV century). Istorisko-pravni zbornik Pravnog fakulteta u Sarajevu 1/2:175-208.

Theunissen H. 1998. Ottoman-Venetien Diplomatics: The Ahd-Names. Electronic Journal of Oriental Studies 1:1-698.

Van Strydonck M, De Moor A, Bénazeth D. 2004. ${ }^{14} \mathrm{C}$ dating compared to art historical dating of Roman and Coptic textiles from Egypt. Radiocarbon 46(1):231-44. 
Figure captions:

Figure 1 (A) The Ahdname (Fojnička ahdnama); Calibrated curve for the weighted mean value of (B) the upper part of the Ahdname, and (C) the lower part of the Ahdname. The arrow in figure $\mathrm{C}$ indicates the expected age.

Figure 2 (A) The Mantel which was assumed to have belonged to Fra Anđeo Zvizdović. Calibrated curves for two textile samples from (B) blue-colored outer layer (the weighted mean value) and (C) red-colored lining material. The arrow in figure $\mathrm{B}$ indicates the expected age.

Figure 3 (A and B) The Fojnica Armorial. Calibrated curves for (C) the thick and (D) the thin paper samples.

Figure 4 Calibrated ${ }^{14} \mathrm{C}$ data distributions for individual and combined data within $2 \sigma$ confidence for the Fojnica Ahdname (Z-5124, the upper part, Z-5126, the lower part), the Mantel of Fra Anđeo Zvizdović (Z-5125, the outer layer, Z-6039, the lining) and the Fojnica Armorial (Z-5700, Z-5701). The dashed line indicates the expected age of the Ahdnama and the Mantel. 

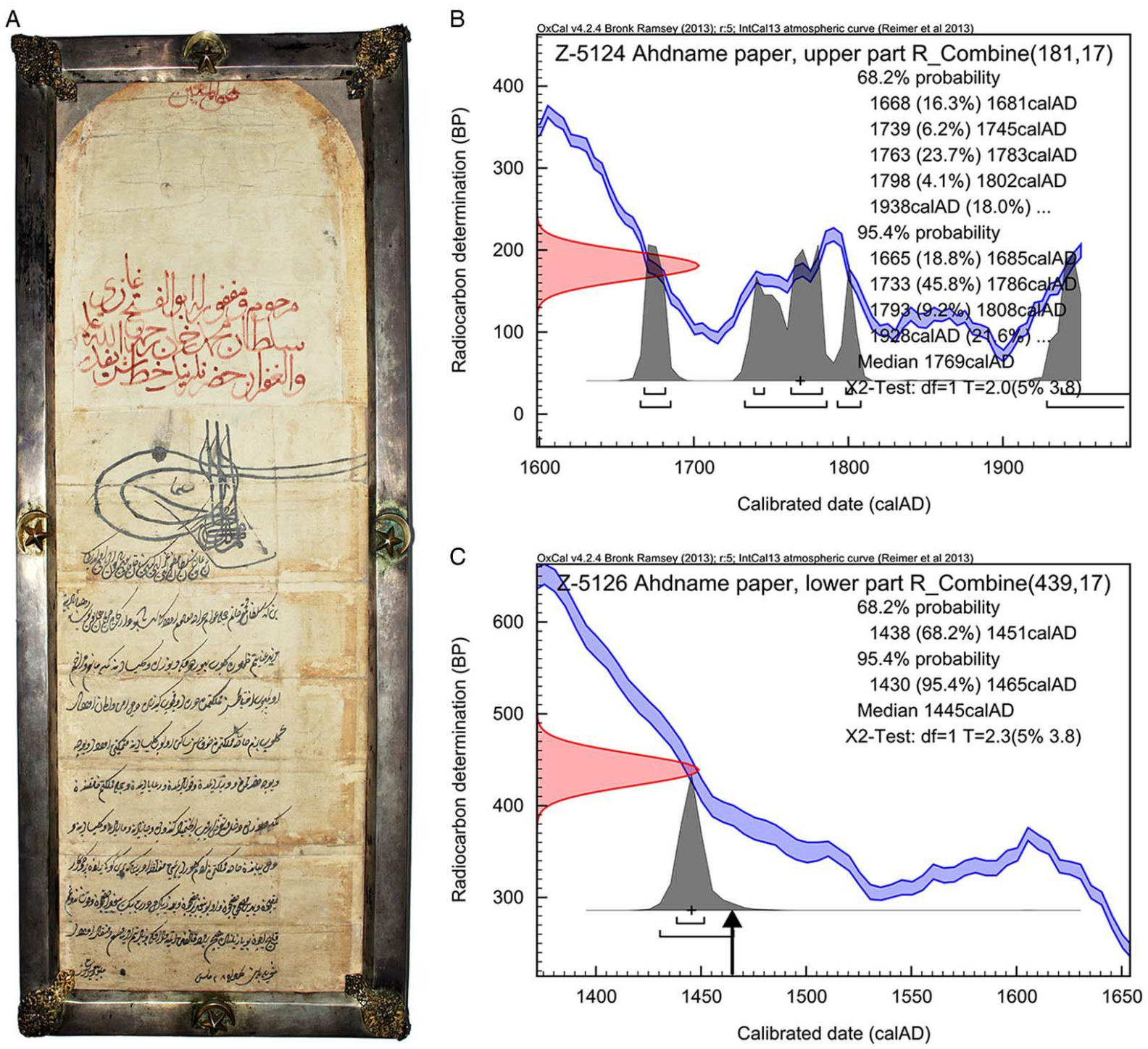

Fig.1. 

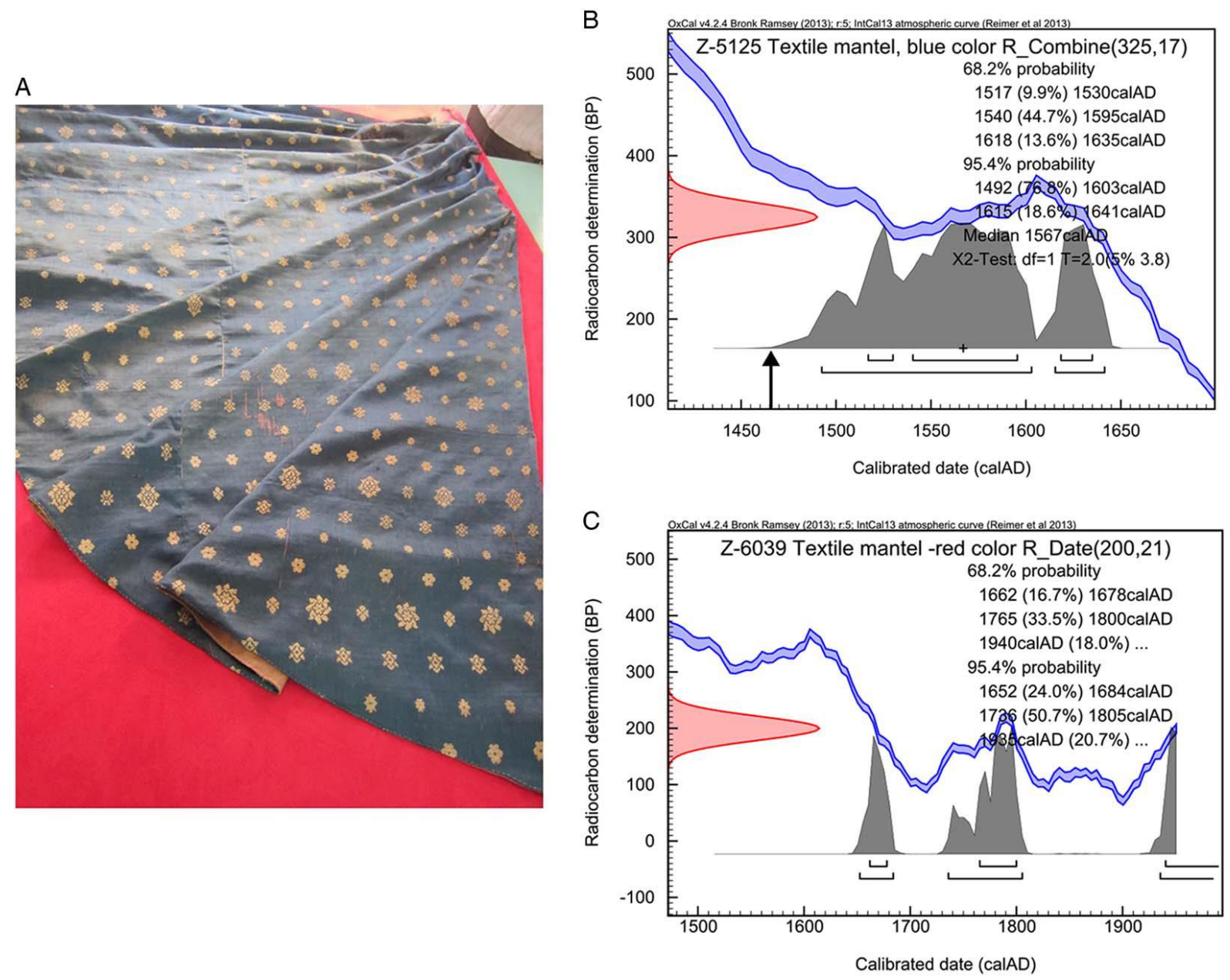

Fig. 2 


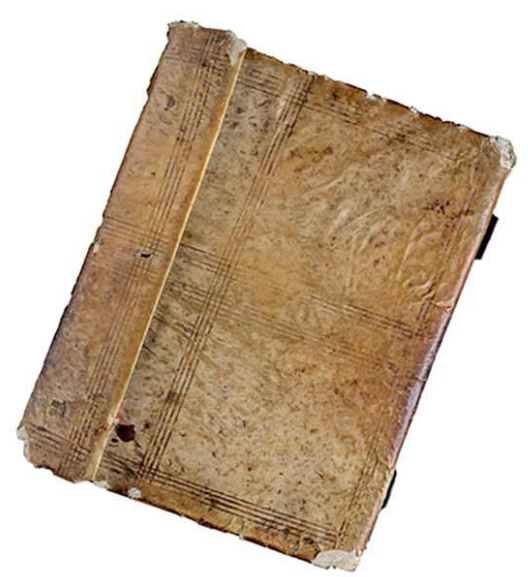

B

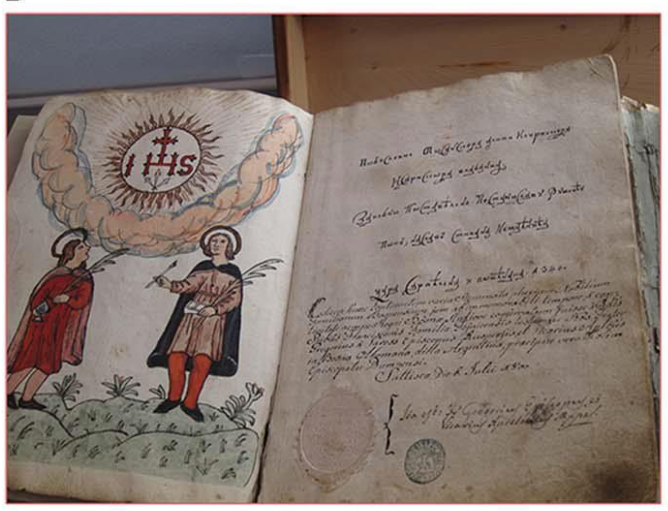

C

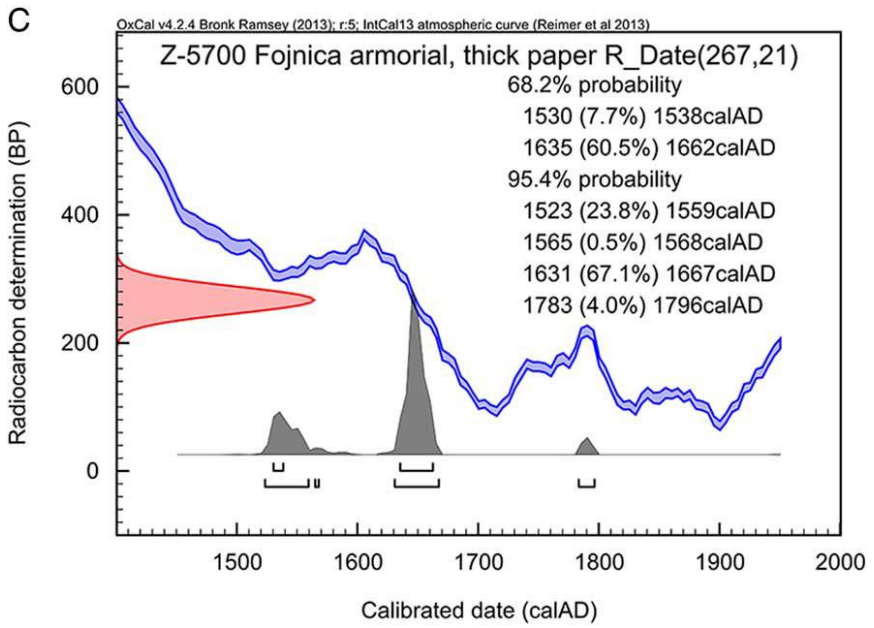

D

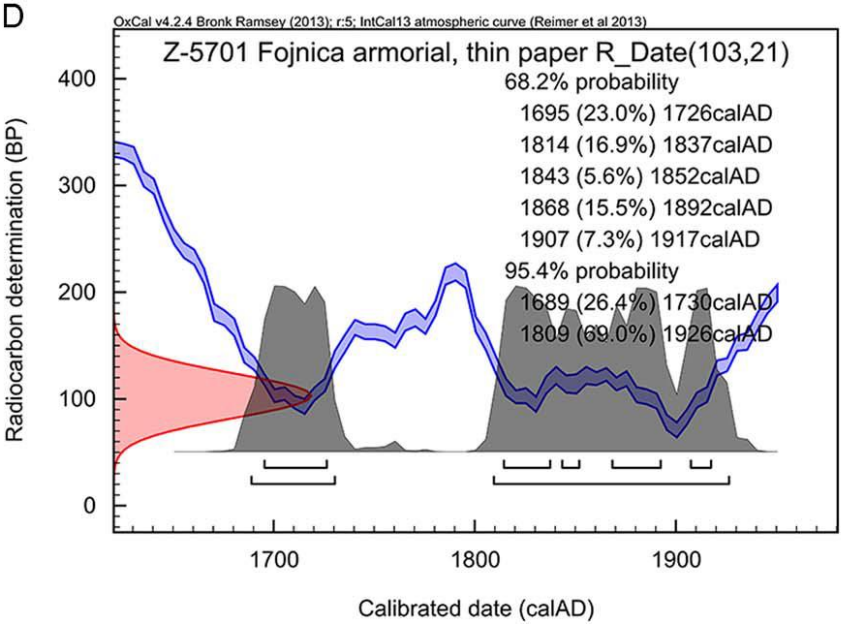

Fig. 3. 
Radiocarbon, 59 (2017), 5; 1359-1368 doi:10.1017/RDC.2017.40

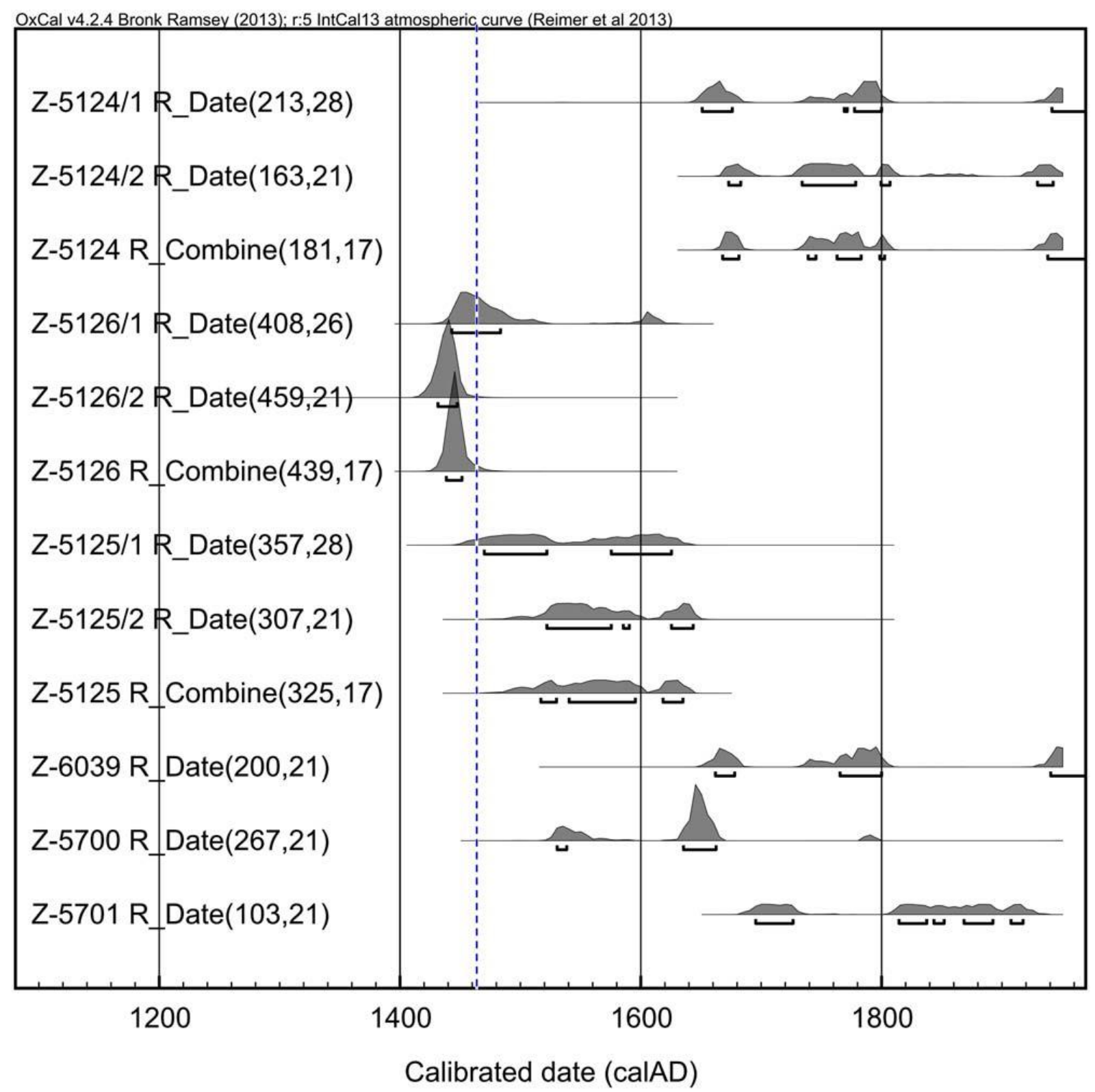

Fig. 4. 